\title{
The structuring principles of Mediation in Portugal
}

\author{
RUBEN BAHAMONDE'
}

GALILEU - REVISTA DE DIREITO E ECONOMIA - e-ISSN 2184-1845

Volume XIX $\cdot 1^{\text {st }}$ July Julho - 31 $1^{\text {TH }}$ December Dezembro $2018 \cdot$ pp. 131-153

DOI: https://doi.org/10.26619/2184-1845.XIX.2.6

Submitted on September $4^{\text {th }}, 2018$. Accepted on November $11^{\text {th }}, 2018$

Submetido em 4 de Setembro, 2018 . Aceite a 11 de Novembro, 2018

ABSTRACT This paper focuses on the description and analysis of the principles that structure and guide mediation as an alternative means of conflict resolution in the Portuguese legal system. To this end, mediation will be individualized and differentiated from other alternative means of conflict resolution, and its advantages and disadvantages will be highlighted. Subsequently, the article will focus on the densification of each of the prevailing principles in mediation: voluntariness, confidentiality, impartiality, responsibility, competence, and enforceability, among others, to identify the interpretive problems that may arise in a practical situation. How these principles interact in the different stages of the mediation process will be explained, as well as the possible subjects of this procedure. Finally, we will make some recommendations for better dissemination and implementation of mediation as a means of conflict resolution.

KEYWORDS Alternative means of conflict resolution, mediation, principles, mediability, voluntariness, impartiality, independence, enforceability.

\section{Conflict and its historical approach}

All societies or collective groups are characterized by a great diversity of individual and collective interests at stake among their elements. This multiplicity of interests generates, of course, several points of friction between interests that may be seemingly antagonistic, thus leading to conflicts ${ }^{2}$.

1 Assistant Professor in the Department of Law of the Universidade Autónoma de Lisboa, Director of the Ratio Legis. Research Centre.

2 In the Portuguese language dictionary, conflict is defined as a clash of opposing elements; discord; antagonism or opposition, See (2017.11.23) https://www.priberam.pt/dlpo/conflito 
Consider, for example, the attribution of an individual or collective right that will necessarily entail the imposition of an equally individual or collective obligation, which will subsequently translate into a potential situation of conflicting interests. However, the existence of conflicts is not in itself positive or negative, but constitutes necessary dynamics for the evolution of the individuals and societies ${ }^{3}$. The positive or negative outcome that may result from the conflict in question is closely connected with how the parties decide to deal with the conflict. Given these assumptions, it can be affirmed that there will be peace when there is good conflict management and absence of peace will be the result of inadequate conflict management.

Our objective in this intervention is not to characterize and qualify the various sources of conflict, but rather to identify the various existing instruments for the management of conflict in order to obtain the best results possible, particularly focusing on mediation. When the management of a conflict results in the satisfaction of the claim of only one party or in the dissatisfaction of both parties, this is a bad result in the outcome of the conflict. However, if the result of the conflict allows for the integration of the conflicting interests in question, it can be easily qualified as positive.

In the most primitive forms of society, self-protection, or making justice by one's own hand was the most common means to resolve conflicts. However, the diversification of individuals and the growth of communities required the creation of objective rules capable of guaranteeing the maintenance of social peace and community life. The famous Law of talion foreseen in the Hammurabi Code, $1780 \mathrm{BC}$, in the kingdom of Babylon, is a clear manifestation of this affirmation that translated into "an eye-for-an eye", making a clear match between the crime committed and the punishment to be had. With this rule, which regulated self-defence, the injured party was granted the right to take revenge on the aggressor, thereby causing the latter the same damage suffered by the former, which increased the scale of the conflict.

The development of social realities demanded the paradigm shift from the traditional self-regulation system to another paradigm of multiple protection, in which the monopoly of the decision in a conflict situation was attributed to a third party, judge or court ${ }^{4}$. It is in this last model of multiple protection that the development of the justice system in mod-

3 See Eduardo Simões, "Gerir Conflitos", José Gonçalves das Neves, Margarida Vaz Garrido and Eduardo Simões, Competências Pessoais, Interpessoais e Instrumentais, 3rd Ed., Edições Sílabo, Lisbon, 2015, pp. 210 and following; Lisa Parkinson, Mediação Familiar, Gabinete para a Resolução Alternativa de Litígios, Ministério da Justiça, Agora Comunicação, 2008, p. 15.

4 CAETANO, Marcelo - História do Direito Português. $4^{\text {a }}$ ed. Verbo, Lisboa 200o, pp. 12-14; DOMINGUES DE ANDRADE, Manuel - Noções elementares de processo civil, Coimbra Editora, Coimbra, 1993, pp. 1-2 e DE FIGUEIREDO DIAS, Jorge - Direito Processual Penal, Coimbra Editora, Coimbra, 2004 pp. 25-26. 
ern societies has been based, with greater or lesser divergences. Indeed, States, through the judiciary, i.e. courts, monopolistically guarantee the obligation to coercively resolve conflicts that are placed before them and which they must know in order to satisfy the effective judicial authorities ${ }^{5}$.

It is clear that the current judicial structures, despite their many virtues, are also characterized by some important failures, such as procedural delays, mental weariness, financial costs, opportunity losses, and the removal of those affected from the decision-making process of their conflict, among others ${ }^{6}$. Then the Alternative Dispute Resolution, which although not totally unknown, appeared at the beginning of the last century and have since played a more important role in the resolution of conflicts, both disseminating them and addressing them more in-depth and in a more systematic way ${ }^{7}$. Before continuing, it should be made clear that despite that fact that the concepts of conflict and dispute have different nuances, since the latter is a kind of the former, in this paper they are used interchangea$b^{8}{ }^{8}$. Thus, within the various means of alternative dispute resolution, we have negotiation, mediation, conciliation and arbitration.

\section{Alternative dispute resolution methods}

The purpose of alternative dispute (ADR) resolution methods is not, in our view, to replace the important role of the judiciary, but rather to complement this function by allowing the parties to a conflict to opt for the method of resolution that is more suitable for the interests at stake, thus giving rise to the concept of "multi-door justice" 9 . An alternative method of settling disputes is one that allows a conflict to be terminated by a route other than a court decision.

In this paper, we will focus on the role of mediation, but in order to better understand this topic, it is essential to characterize, albeit succinctly, the remaining methods of alter-

5 Issues that do not have to be taken before a judge.

6 See Justice in the EU Review Panel for the year 2017 published on 10 April, available at (2017.11.23): europa.eu/rapid/ press-release_IP-17-890_pt.pdf

7 A. Fernández Barreiro, Javier Paricio, Fundamentos de Derecho Privado Romano, 3rd Ed., Editorial Centro de Estudios Ramón Areces, 1997 pp. 140-142, noting that in parallel with ordinary jurisdiction, there have been private arbitrations since II.BC., and also arbitrations in which the parties were obliged to submit the dispute to the assessment of an arbitrator over institutional jurisdiction. Mariana França Gouveia, Curso de Resolução Alternativa de Litígios, 2nd Ed. Almedina, Coimbra, 2012, pp. 25-28.

8 Dulce Lopes, Afonso Patrão, Lei da Mediação Comentada, 2nd Ed., Almedina, Coimbra, 2014, pp. 12-13.

9 Ibid. 26. This idea is further reinforced by the fact that in the Portuguese legal system, Article 273 of the Code of Civil Procedure provides for the possibility of suspension of proceedings to resort to mediation and should this fail, then this suspension will automatically cease and the case will again be decided by the Judge. 
native dispute resolution. They may be characterized as voluntary or compulsory, adjudicatory or consensual and based on principles or on the law.

Firstly, we have a voluntary alternative method when the parties willingly submit the conflict in question to resolution by that particular means. On the contrary, the method will be compulsory when the parties are unable to resolve the dispute through a means of their choice, as for example in compulsory arbitration.

Secondly, there will be alternative adjudicatory methods of settling disputes when the parties give a third party the power to decide on the dispute, and undertake to comply with the decision. Conversely, the method will be consensual when the parties are able to accept or not a given result. This is known as empowerment, or being in command of the process.

Finally, the conflict can be resolved by taking into account purely legal criteria, i.e. in accordance with positive law, or it can be settled by following principles such as equity. The characterization of the various alternative methods of settling disputes is made clearer by the following table:

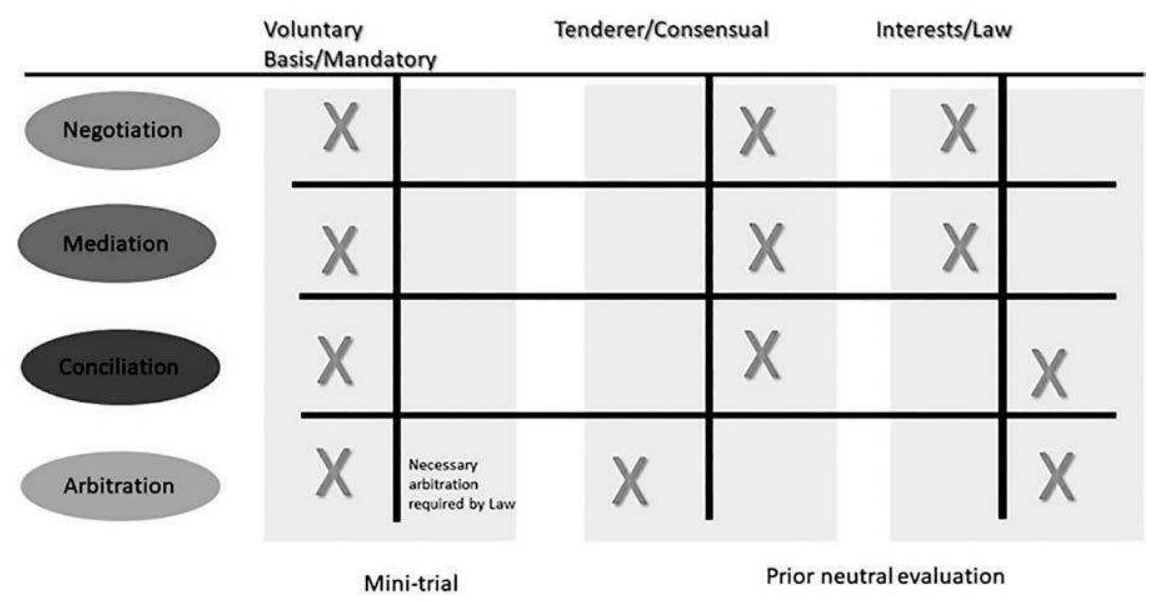

The first alternative method of dispute resolution referred to is negotiation. There are some authors who disregard this form as an alternative form of settling disputes by stating that it is a technique that can be used in any of the other alternative methods of dispute resolution, so it would be merely instrumental. However, in our view, such an understanding does not remove from negotiation its own entity and autonomy, insofar as it may be the only method used to resolve a conflict effectively without having to resort to any other.

Negotiation as a conflict resolution technique is used daily by all people in the most diverse contexts, and there are several negotiation methods, such as disruptive negotia- 
tion, negotiation of positions, or negotiation of interests, among others ${ }^{10}$. In the field of negotiation, the principled negotiation postulated by Harvard's choice has been gaining ground. It is based on an integrative and objective principle aimed at maintaining relations between the parties involved in the process in question ${ }^{11}$. In negotiation, the parties to the conflict have full control over the process and voluntarily decide whether to abide or not by the outcome of the process. The advantage of this method is the satisfaction of the claims of both parties, allowing a better and more peaceful maintenance of their relationship through a reciprocal commitment solution.

With regard to arbitration, and because it is not the main part of our subject, we can briefly characterize it as the alternative means of settling disputes that is more similar to the judicial process. This variant is an adjudicatory conflict heterocomposition method that may be voluntary or compulsory, as the case may be, and that may be about principles or about law, the latter being the most frequent ${ }^{12}$. The alleged advantage of this method traditionally consists in its great celerity, in its confidential nature and in the significant reduction of costs for the parts. Nevertheless, these attributes are not peacefully accepted by the doctrine ${ }^{13}$. In contrast to negotiation, in arbitration the parties are usually represented by others, and will typically deal with legal issues, not interests, and therefore the process always results in a loser and a winner. Thus, this form of dispute resolution does not take into account the re-establishment or maintenance of the relationship between the parties to the dispute, but only the decision as to whether the position adopted by each of them is legal or not.

\section{Mediation in Portugal}

Broadly speaking, the consecration of mediation as a form of settling disputes was reinforced in the Portuguese legal system in 2001, through article 16 of Law no. 78/2001, of 13 July, which created the Justice of the Peace ${ }^{14}$, by creating a mediation service within them..$^{15}$

10 See Eduardo Simões, "Negociar", José Gonçalves das Neves, Margarida Vaz Garrido and Eduardo Simões, Competências Pessoais, Interpessoais e Instrumentais, 3rd Ed., Edições Sílabo, Lisbon, 2015, pp. 233 and following. In a disruptive negotiation and in a negotiation of positions, there is a single negotiating interest that ends necessarily with a winner and a loser, the buyer wants to pay less and the seller wants to receive more.

11 Roger Fisher, William Ury and Bruce Patton, Como conduzir uma negociação, Translation by Maria João Goucha, 9th Ed., Lua de Papel, Lisbon, 2010.

12 Manuel Pereira Barrocas, Manual de Arbitragem, 2nd Ed., Almedina, Coimbra, 2013.

13 Jordi Nieva-Fenoll, "Mediación y Arbitraje: Una ilusión decepcionante?", Rafael Cabrera Mercado (Dir.) Pedro M. Quesada López (Coor.), La mediación como método para la resolución de conflictos, Dikinson, Madrid, 2017, pp. 15- 17.

14 This diploma on Justice of the Peace - Organization, competence and functioning was amended by Law no. $54 / 2013$, of $31 / 07$

15 The jurisdiction of the Justice of the Peace is limited to declaratory actions (article 6), whose amount does not exceed $€ 15.000,00$ (article 8) and whose matters fall within the list provided for in Article 9. 
Subsequently, following the publication by the European Commission of the European Code of Conduct for Mediators in $2004^{16}$ and the Directive on cross-border mediation in civil and commercial matters in $2008^{17}$, the legislator published Law no. 29/2013, of 19 April, where the institution of mediation in Portugal is definitively and autonomously established ${ }^{18}$. A few months later, a specific European Directive was published on the alternative resolution of consumer disputes, which also consecrated mediation ${ }^{19}$.

In the European Code, mediation is defined as a process in which two or more parties agree to appoint a third party, the mediator, to assist them in resolving a conflict through an agreement without a ruling, regardless of how the process may be conducted in each Member State. In turn, Article 2 of the Portuguese Mediation Law welcomes the definition proposed by Directive 2008/52/EC and defines mediation as the form of alternative dispute resolution, carried out by public or private entities, through which two or more parties in conflict voluntarily seek to reach an agreement with the assistance of a conflict mediator ${ }^{20}$.

Accordingly, mediation is a process of self-protection that has the assistance of an impartial and independent third party, the mediator, deprived of powers of imposition to the parties, who assists them in the attempt to reach a final agreement on the object of the dispute. This mediating process, depending on the degree of intervention of the mediator, may be of an interventional nature, as the mediator is able to make proposals and values the merits of the issues, or it may be of a facilitative nature when the mediator's functions are restricted to the creation of channels of communication and understanding between the parties. It is this last model, of facilitating mediation, that was chosen by the Portuguese legislator. Such choice does not imply the discrediting of other methods of mediation ${ }^{21}$.

As regards the objectives sought by mediation, it is also clear from the Portuguese rule that we are faced with a process aimed at reaching an agreement between the parties, the positive outcome of which will depend precisely on the implementation of the agreement. Notwithstanding the foregoing, it has been argued that this kind of mediation directed at

16 Available at (2017.11.23): http://www.dgpj.mj.pt/sections/gral/mediacao-publica/mediacao-anexos/codigo-europeu-de/downloadFile/file/Codigo_Europeu_de_Conduta_para_Mediadores_13.03.2014.pdf?nocache $=1394707997.85$

17 Directive 2008/52/CE of the European Parliament and of the Council of 21 May 2008, on certain aspects of mediation in civil and commercial matters.

18 Law no. 29/2013, of 19 April, General Principles Applicable to Mediation - Civil and commercial mediation. For a detailed analysis of legislative developments in Portugal on mediation see Jorge Morais de Carvalho, "A Consagração legal da mediação em Portugal", Julgar, vol. 15, pp. 272-273.

19 Directive 2013/11/EU of the European Parliament and of the Council of 21 May 2013 on alternative dispute resolution for consumer disputes, amending Regulation (EC) no. 2006/2004 and Directive 2009/22/EC.

20 See (a) of Article 3 of the Directive, which defines mediation as a structured process, regardless of its designation or the way in which it is referred to, by which two or more parties to a dispute voluntarily seek agreement on the resolution of the dispute with the assistance of a mediator.

21 Mariana França Gouveia, Curso de Resolução ..., pp. 43-44. 
the agreement, typical of civil and commercial mediation, does not prove to be the best technique to mediate conflicts of another nature, such as family or criminal. In these cases, other models such as transformative mediation, ecosystemic mediation or narrative mediation are proposed. ${ }^{22}$

Currently in Portugal, there are public and private mediation systems. In the field of public mediation we can also distinguish between the mediation of generic competence, materialized in the Justice of Peace courts ${ }^{23}$, and the specialized mediation in the labour ${ }^{24}$, criminal ${ }^{25}$ and family area ${ }^{26}$.

\section{A. The defining characteristics of mediation.}

As noted above, mediation is a process directed by a third party, the mediator, whose intervention is voluntarily requested by the parties to the dispute to assist them in obtaining a peaceful resolution of their dispute. As a method, and in contrast to judicial processes, mediation is distinguished by its informality, speed, and concern for the relationship between the mediated parties.

The exercise of justice within the judicial courts is characterized by high formalism that does not go unnoticed among those summoned there. It begins with the very disposition of the courtroom, where the Judge occupies a central and high place, while the parties sit in a lower position. The dark robes used by lawyers and judges also confer this formal and solemn character to the realization of justice.

At a trial, the judge directs the various procedural steps with authority, following the corresponding rules without giving the parties the possibility to change course. Regarding

22 On these types of mediation, see Lisa Parkinson, Mediação Familiar..., p. 42-53.

23 See articles 16 and 30-36 on the figure of the mediator and articles 49-56 on pre-mediation and actual mediation. On this, see João Chumbinho, Julgados de Paz na Prática Processual Civil, Quid Juris, Lisbon 2007 and João Miguel Galhardo Coelho, Julgados de paz e Mediação de Conflitos, Âncora Editora, Lisbon, 2003.

24 Labour Mediation System (SML) - Protocol of 5 May 2016 by the Ministry of Justice and the Social Partners to mediate conflicts resulting from individual employment contracts that deal with available rights and not resulting from an accident at work. Articles 525-528 of the Labour Code should also be stressed as far as collective labour disputes are concerned. On this matter, see António Casimiro Ferreira, "O sistema de resolução dos conflitos de trabalho: da formalização processual à efetividade das práticas", Revista Crítica de Ciências Sociais, no. 60, 2001, pp. 9-32.

25 Criminal Mediation System (SMP) - Law No. 21/2007, of 12 June, dealing with private crimes and some semipublic crimes. On this matter, see Mário Ferreira Monte, "Um balanço Provisório sobre a Lei de Mediação Penal de Adultos", Homenagem de Viseu a Jorge Figueiredo Dias, Paulo Pinto de Albuquerque (coord.), Wolters Klower, Lisbon, 2011. pp. 113-127.

26 Family Mediation System (SMF) - Dispatch No. 18, 778/2007, of 13 July. On this matter, see Rossana Martingo Cruz, Mediação familiar: Limites materiais dos Acordos e o seu controlo pelas Autoridades, Coimbra Editora, Coimbra, 2011 and Lisa Parkinson, Mediação Familiar, Gabinete para a Resolução Alternativa de Litígios, Ministério da Justiça, Agora Comunicação, 2008. 
mediation, although it is a structured process divided into several phases ${ }^{27}$, there is great flexibility that allows the mediator, together with the parties, to choose and establish the best organization of the process for the resolution of the conflict ${ }^{28}$. In addition, in mediation the physical environment in which the process is carried out is important, and conditions must be provided to foster equality and proximity between the parties, enabling them to assume the role of advocates of conflict resolution ${ }^{29}$. Finally, this simplicity is also due to the absence of lawyers in the mediation process, which facilitates and encourages direct communication between the parties involved..$^{30}$

The duration of the process is also seen as an advantage over traditional court forms, which is an express concern of the legislator when establishing, in many cases, a maximum period of three months, without prejudice to the fact that, at the request of the parties, it can be extended ${ }^{31}$. As far as private mediation is concerned, the law does not impose a maximum length of time for the process, for which reason it will be freely established by the institution concerned, as prescribed in Article 21 of the Mediation Law. The length of the judicial cases, which in Portugal generally allow a decision at a Court of First Instance within two years, would clearly be longer than in the deadline allocated to mediations ${ }^{32}$.

Lastly, the purpose of mediation is not to resolve the dispute on the basis of the legal merit of each of the parties' claims, but rather to promote the pacification of the parties, encouraging them to develop communication channels that allow them to come up with a stable, long-term and voluntary solution ${ }^{33}$. Moreover, mediation is not limited to resolving the existing conflict by obtaining an agreement, since it also aims to prepare the parties to

27 Javier Alés Sioli, Juan Diego Mata Chacón, Manual Práctico para Mediadores. El misterio de la mediación. Como gestionar un conflicto desde sus cenizas., Atelier, Barcelona, 2016, pp. 181-182; Mariana França Gouveia, Curso de Resolução..., pp. 62-78.

28 This absence of formality is specifically consecrated in labour mediation. See no. 2 of article 24 of the Manual of Procedures and Good Practices of the Labour Mediation System, Article 2 of Dispatch 18778/2007 and no. 1 of article 4 of Law 20/2007 of 12 June on criminal mediation. On this flexibility, see Enrique César Pérez Luño Robledo, "La mediación como Proceso?", Rafael Cabrera Mercado (Dir.) Pedro M. Quesada López (Coor.), La mediación como método para la resolución de conflictos, Dikinson, Madrid, 2017, pp. 54.

29 Roger Fisher, William Ury and Bruce Patton, Como conduzir uma negociação p. 178

30 For example, in the Justice of the Peace Courts the presence of the parties is compulsory, pursuant to article 38 of Law 78/2001 of 13 July. As for private mediation, the parties may be represented by others, pursuant to article 18 of Law 29/2013 of 19 April.

31 See no. 1 of article 21 of Law 29/2013 of 19 April, Point 6 of Directive 2008/52/EC, emphasizing the virtues of mediation as a quick and inexpensive solution to the dispute. Specifically, the public systems of criminal, labour, and family mediation in Portugal have a maximum duration of 3 months Cf. Article no. 1 of Law 21/2007 of 12 June; paragraph g) of Clause 4 of the Protocol.

32 See Point 3.1.1.1, figure 4 of the 2017 EU Justice Scoreboard published on 10 April 2017, available in (2017.11.23): europa.eu/rapid/press-release_IP-17-890_pt.pdf.

33 Jean Françoes Six, Veronique Mussaud, Médiation, Seuil, Paris, 2006, pp. 26 and following. 
resolve future conflicts between them ${ }^{34}$. Thus, although civil and commercial mediation is particularly geared to reaching an agreement between the parties, with regard to mediation in other areas such as the family, failure to reach an agreement can be a good result if the process have enabled the parties to open channels of dialogue and understanding of the interests and motivations of the parties ${ }^{35}$.

\section{B. The structuring principles of mediation}

As seen above, mediation is based on a specific conflict resolution logic that has resulted from concrete concerns about the traditional legal process regarding delays and distancing the parties from the solution. In order to safeguard the purposes it proposes, the mediation process must observe several principles, namely voluntariness, confidentiality, equality and impartiality, independence, responsibility, and enforceability ${ }^{36}$.

\section{a) Principle of voluntariness}

This principle is enshrined in Article 4 of the Mediation Law and implies that the use of mediation requires the informed consent of the parties and that the parties are responsible for decisions taken during the process ${ }^{37}$. As a result of this principle, the parties may, at any time during the mediation procedure, revoke their consent and withdraw from the mediation in progress without having to justify their decision, contrary to what happens in conciliation.

The principle of voluntariness is also evident in the adoption of the agreement eventually drawn up by the parties in so far as it is binding only if they accept it freely. The principle of voluntariness is not impaired in cases where a compulsory mediation system is imposed that entails the verification of mediation as a prerequisite, i.e. an action could only be brought before the courts once the mediation route has been exhausted.

As the doctrine broadly states, a compulsory mediation system on the terms set out would be within the scope of no. 1 of Article 20 of the Constitution of the Portuguese Republic (CRP) and Article 6 of the European Convention on Human Rights, as it does not

34 M. Lozano Martín, Tratado de mediación en la resolución de conflictos, Tecnos, Madrid, 2015, pp. 120 and following.; Lisa Parkinson, Mediação Familiar..., p. 19.

35 Javier Alés Sioli, Juan Diego Mata Chacón, Manual Práctico para Mediadores..., p. 108, states that, since an agreement is a positive outcome, "both the mediator and the parties to the dispute must consider that the decision not to reach agreement is an equally valid conclusion".

36 Articles 3-4 of the Mediation Law, Dulce Lopes, Afonso Patrão, Lei da Mediação Comentada... pp. 29-72; Enrique César Pérez -Luño Robledo, "La mediación como Proceso? ...", p. 54.

37 The principle of voluntariness is also implicitly enshrined in Directive 2008/52/EC of the European Parliament and of the Council of 21 May 2008 on certain aspects of mediation in civil and commercial matters, in particular Article 3 paragraph (a). 
prevent access to the effective judicial authorities and whenever such a prerequisite is not detrimental to the legal situations in question and appears necessary, proportionate and reasonable ${ }^{38}$. As we have seen, the parties cannot be harmed by the use of mediation, but another question posed here is the possibility of the State to encourage the use of alternative means of dispute resolution, in particular mediation, conferring advantages to those who use them. In these situations, there appears to be no obstacle to such a policy, since they are designed to ensure a better functioning of the system of administration of justice $^{39}$. (In Argentina there are sanctions).

Finally, within this voluntariness also lies the ability of the parties to choose the mediator or mediators who will guide the process as prescribed in Article 17 of the Mediation Law. This freedom suffers some deviations in the case of public mediation where the arbitrator is chosen randomly from among the mediators registered in the respective lists constituted for the purpose ${ }^{40}$. This feature is in clear opposition to the principle of the natural judge that prevails in ordinary jurisdiction and is enshrined in no. 9 of Article 32 of the CRP.

\section{b) Principle of confidentiality}

Article 5 of the Mediation Law establishes the confidentiality of the process, and the mediator must keep confidential all information he or she has knowledge of in the context of the mediation procedure, and may not use it for his/her own benefit or for the benefit of others. This principle also implies that the information revealed by one of the parties to the mediator cannot be communicated to the other party without the consent of the former, which is what happens in private or caucus sessions ${ }^{41}$.

Confidentiality is a fundamental pillar in the promotion of alternative means of conflict resolution and in particular in mediation. In effect, the parties would have very little openness to share or disclose information that was not accessible to the other party if such information could subsequently be used in court if mediation were thwarted. Moreover, in

38 Jorge Morais de Carvalho, "A Consagração legal da mediação ... p. 281. This issue is approached in the same way in the Spanish legal system. See Héctor Âlvarez Garcia, "La premediación como presupuesto procesal de admisibilidad versus el derecho fundamental de acceso a la jurisdicción", Rafael Cabrera Mercado (Dir.) Pedro M. Quesada López (Coor.), La mediación como método para la resolución de conflictos, Dikinson, Madrid, 2017, pp. 89 and following.

39 Dulce Lopes, Afonso Patrão, Lei da Mediação Comentada... pp. 36-37; Cátia Marques Cebola, "A mediação préjudicial em Portugal: Análise do Novo Regime Jurídico", Revista da Ordem dos Advogados, Ano 70, nos. 1-4, 2010, pp. 441-459. As this author points out, it is only with these incentives or privileges, such as the suspension of deadlines, that "it is possible to affirm it as a method of resolving conflicts of value similar to the judicial system, in the sense that it is an option that does not preclude the rights of the parties to find a solution to their conflict".

40 See. no. 1 of article 3 of Law no. 21/2007, of 12 June (criminal); point b) of no. 2 of article 3 of Dispatch 18778/2007 (family), point 4 of Agreement Protocol (labour).

41 Mariana França Gouveia, Curso de Resolução ..., p. 64. 
order for the mediation process to be effective, it is necessary for the parties to be dynamically involved in the solution of the problem, which is only possible after the interests of each party have been shared ${ }^{42}$.

The requirement of this confidentiality is also evident in the mediation that takes place in the Justice of the Peace Courts, in labour mediation ${ }^{43}$, in family mediation ${ }^{44}$, in criminal mediation ${ }^{45}$, in the European Code of Conduct for Mediators ${ }^{46}$ and in the Directive on mediation ${ }^{47}$, so its essentiality in the mediation process is undeniably expressed.

This confidentiality, which must be respected by both the mediator ${ }^{48}$ and the parties, is not absolute. Deviations are foreseen in the case of compelling reasons of public order, in particular to ensure the protection of the best interests of the child, or when protecting the physical or psychological integrity of a person is at stake.

The enumeration of cases which derogate from the principle of confidentiality is not exhaustive, and this principle may decline whenever rights or interests whose protection is greater than those protected by the principle are involved, i.e. the success of mediation ${ }^{49}$. The principle of confidentiality may also be disregarded when this is necessary for the purpose of implementing the agreement reached, but only in so far as it is particularly necessary to protect the interests ${ }^{50}$. Finally, a third cause for deviating from the principle of confidentiality of the agreement would be the very will of the parties being mediated. It makes sense that a process of a voluntary nature characterized by its flexibility allows the mediated parties to waive the principle of confidentiality, being allowed to use all the information obtained during the procedure. However, a different question is to know the effect of this negotiating declaration of the parties towards the mediator. At this point, we agree with Dulce Lopes and Afonso Patrão's understanding that such a declaration between the mediated parties does not oblige nor can it force the mediator to disregard confidentiality,

42 Dulce Lopes, Afonso Patrão, Lei da Mediação Comentada... pp. 36-37.

43 See no. 2 of Article 24 of the Manual of Procedures and Good Practices of the Labour Mediation System available at (2017.11.23): http://www.dgpj.mj.pt/sections/gral/mediacao-publica/mediacao-anexos/manual-de-boaspraticas/downloadFile/file/SML_Manuel_boas_praticas.pdf?nocache $=1351089425.34$

44 See Article 2 of Dispatch 18778/2007, which establishes that the FMS conducts its activity while guaranteeing voluntariness, celerity, proximity, flexibility and confidentiality.

45 No. 5 of Article 4 of Law 20/2007 of 12 June on criminal mediation expressly provides that the content of mediation sessions is confidential and cannot be assessed as evidence in court proceedings.

46 Point 3.1 of the European Code of Conduct for Mediators.

47 Article 7 of Directive 2008/52/EC of 21 May 2008 on certain aspects of civil and commercial mediation. him, May pean Qualifications Frsame way in the Spanish legal system onclude have of himve known him, May pean Qualifications Fr

48 Article 28 of the Mediation Law specifically states that the conflict mediator cannot be a witness, expert or agent in any case related to the subject of the mediation procedure.

49 Dulce Lopes, Afonso Patrão, Lei da Mediação Comentada... pp. 49 and following.

50 See no. 3 of article 5 of the Mediation Law. 
thus jeopardizing another principle as or more important than that one, the independence of the mediator ${ }^{51}$.

Indeed, it is our understanding that the mediator will have the independent conduction of the conflict compromised in view of the possibility of being a witness in a process, since one thing is to remain impartial as a conflict mediator and a very different thing is to answer questions involving his perception and judgement of the mediation procedure as a witness in a judicial context ${ }^{52}$.

The legislator does not mention in the law who will be the person/entity with authority to decide about the verification of the assumptions for lifting confidentiality, and it is agreed that the doctrine states that such authority lies with the mediator ${ }^{53}$. However, in our opinion this option does not seem to be the right one. It is true that the mediator does not belong to any professional association, as it happens in the case of lawyers, who can verify the existence of the assumptions to carry out the lifting of professional secrecy ${ }^{54}$. However, it is very similar to the need for such a requirement in the field of law, in order to guarantee the impartial and independent performance of the mediator's functions.

Indeed, the parties will have more confidence in the procedure if they have serious assurances that the confidentiality of the case depends not only on the mediator's interpretation but also on objective criteria to be interpreted by a third party. Moreover, the civil responsibility of the mediator does not satisfy either Greeks or Trojans. On the one hand, the mediated parties do not use an alternative means of settling disputes with the guarantee that they can start another judicial procedure to hold the mediator liable in case of breach of the duty of confidentiality. On the other hand, it is clear that the mediator has much to gain and little to lose by risking an interpretation on the deviation of the principle of confidentiality by being subject to possible repercussions on civil and criminal liability. In view of the fact that the deviation from the principle of confidentiality arises from a greater interest than mediation and the mediated parties, it seems more appropriate that such interest be protected by another independent body that may be part of institutional-

51 Dulce Lopes, Afonso Patrão, Lei da Mediação Comentada... pp. 51.

52 With a clearly opposite view, the Spanish legislator, specifically in point a) of no. 2 of Article 9 of Law 5/2012, of 6 July, about mediation in civil and commercial matters, states that the parties can dispense with express and written agreement the obligation of the mediator's confidentiality. This was also the understanding set out in Article 7 of Directive 2008/52/EC of 21 May 2008.

53 Mariana França Gouveia, Curso de Resolução ..., p. 85; Dulce Lopes, Afonso Patrão, Lei da Mediação Comentada... pp. 52 and following.

54 Article 92 of the Statute of the Lawyers Association. 
ized mediation, whether public or private, thus safeguarding the mediator's position and independence ${ }^{55}$.

Infringement of the principle of confidentiality may have a number of consequences in view of the offending agent and the use made of the information obtained. Firstly, information obtained in breach of the confidentiality principle that is not covered by any of the above exceptions, cannot be assessed in a court or arbitral entity, which will safeguard the position of the mediated party that might be affected by this behaviour. Secondly, with respect to the mediator, such behaviour may give rise to the corresponding civil liability and other sanctions and even penal measures may be applied for infringing secrecy ${ }^{56}$.

The confidentiality of the mediation process also constitutes an essential difference with the principle of publicity that prevails in judicial bodies pursuant to Article 206 of the CRP and that makes alternative means of settling disputes more appealing. This will be the case, for example, of disputes where one of the parties has no interest in disclosing the outcome of the conflict in order to prevent third parties in similar situations from being encouraged to claim their rights by securing a precedent favourable decision. In addition, if mediation is not successful, the mediator will not have any other connection with the resolution of the dispute, which prevents that information from having any influence on the outcome of the dispute. As will be seen, this is no longer the case in the case of conciliation.

\section{c) Principle of equality and impartiality}

The principle of equality and impartiality enshrined in Article 6 of the Mediation Law requires the parties to be treated fairly throughout the mediation process, and the dispute mediator must manage the procedure in such a way as to ensure the balance of powers and the possibility of both parties participating in it. In our view, the application of this principle necessarily requires respect for the audi alteram partem principle, which, although not specifically enshrined in the diploma, is a mandatory consequence of ensuring equal treatment ${ }^{57}$. However, the equality postulated in this area will always be tempered by the mediator's criterion, which, given the specific characteristics of the conflict and the power

55 Dulce Lopes, Afonso Patrão, Lei da Mediação Comentada... p. 52, states that there would even be a duty of the mediator to breach confidentiality which could, in case of omission, cause the mediator to incur in a crime of omission of aid. As we have said, for us this position is very rigid and inadequate to safeguard the interests at stake. The courts will find it very difficult to prove the illegitimacy of a possible omission of aid in this area by the mediator and the mediator will find it very difficult to assume a position of breach of confidentiality without any support that jeopardizes his functions

56 See no. 2 of Article 8 regarding public mediation and article 44, both of the Mediation Law and Article 195 of the Criminal Code.

57 This is also the understanding of Enrique César Pérez -Luño Robledo, "La mediación como Proceso?", pp. 47 and following. 
of each of the mediated parties, should lead to mediation in order to ensure an adequate balance that can compensate for differences of power between the mediated parties.

In short, this principle is intended to ensure the transparency of the mediation procedure so that the parties have full confidence in the process inf which they become an active part, obtaining and reading information, expressing their opinions and cooperating in the definition of the terms of the agreement to be concluded. If, on the other hand, the mediator finds that there is a situation of difference in power between the parties that hampers the resolution of the conflict in compliance with the principle of equality, he may and should, if he deems it appropriate, terminate the mediation procedure as provided for in c) of article 19 of the Mediation Law. The mediator has the duty to balance the forces by suggesting that the parties request the opinion or intervention of specialized technicians in a given subject when this proves necessary or useful to the clarification and well-being of the parties ${ }^{5}$.

The impartiality of the mediator in the context of the mediation procedure is appreciably different from the impartiality required from the judge, insofar as, as a general rule, the mediator is not aware of the dispute to be mediated, understanding it only in the first mediation or pre-mediation session, so he will have a more open mind. The observance of this principle, besides being a duty, also stems from the regime of impediments and excuse of the mediator that the law consecrates ${ }^{59}$. The impartiality of the mediator must be present before, during and after the conclusion of the mediation process. The mediator must not accept mediation when he considers that there is a motive that prevents the performance of his function in accordance with this principle. The mediator must also excuse himself from the function when, during the course of the mediation, he notices the emergence of some reason that affects his impartiality. Finally, the mediator must refrain from advising any of the mediated parties after the conclusion of the mediation procedure ${ }^{60}$.

\section{d) Principle of independence}

In the performance of his duties, the mediator must guide his conduct with independence, free from any pressure whatsoever, whether resulting from his own interests, personal values or external influences. Thus, when the mediator considers that due to legal, ethical

58 See point g) of Article 26 of the Mediation Law.

59 See point f) of Article 26 and Articles 27 and 28 of the Mediation Law.

60 See Article 28 of the Mediation Law. In effect, this precept prohibits the mediator from representing any of the mediated parties, in any related cause, even if indirectly, in the mediated conflict. Indeed, it seems difficult to imagine how the mediator can be a representative of one of the mediated parties in a given process, which, although he has nothing to do materially with the mediated process, cannot be indirectly related, raising reasonable suspicions about the partiality or interest of the mediator. 
or deontological reasons, his independence, impartiality or exemption may be compromised, he should not accept his appointment as a mediator of conflicts, and if he has already initiated the procedure, he must interrupt it and ask to be taken away as soon as he realizes that his independence is or may be affected ${ }^{61}$. Examples of situations that may harm the mediator's impartiality are the personal or professional relationship that he may have with one of the parties or the existence of a direct or indirect financial interest in the outcome of mediation ${ }^{62}$.

The principle of independence is not confused with the principle of impartiality, as the latter requires neutral treatment of the mediation and object of mediation, and the former focuses on verifying that there is no mediator's links that might compromise his or her function by not by exercising it in full freedom, whether these links are exogenous, subordinated to or the influence of a third party, whether endogenous, like values, personal interests, etc. ${ }^{63}$ On the other hand, the duty of independence is the other side of the coin of the right of the conflict mediator to exercise mediation independently, as provided for in point a) of Article 25 of the Mediation Law.

\section{e) Principle of competence and responsibility}

Article 8 of the Mediation Law does not require any specific training for the exercise of mediation activity. It merely refers that mediators can attend training courses that give them specific theoretical and practical skills, namely a training course for conflict mediators carried out by a training entity certified by the Ministry of Justice. Thus, it follows from this provision that it is not compulsory to attend courses certified in accordance with article 24 of the Mediation Law in order to exercise the profession of mediator, only but for purposes of public mediation ${ }^{64}$. However, as will be seen below, the enforceability of the agreement reached in Mediation is a strong incentive for the parties to the conflict to choose mediation as a form of resolving the conflict in a swift, participatory and definitive manner. It follows that, if such mediation is not conducted by a mediator included on the

61 See Article 7 and no. 3 of Article 27 of the Mediation Act and point 2.1 of the European Code of Conduct for Mediators.

62 See supra, with regard to the principle of impartiality, our assertion when considering that even the provision of services by the mediator to one of the parties once the mediation is concluded may question the impartiality and independence of the mediator. See point 2.1 of the European Code of Conduct for Mediators.

63 In practice, the impartial mediation of a dependent mediator can be verified, and the reverse, an impartial mediation by an independent mediator. Indeed, the combination of partiality and independence generate greater assurance and confidence in the process and in the function of the mediator.

64 This is the conclusion that results from no. 5 of Article 24 (5) of the Mediation Law. 
list of conflict mediators organized by the Ministry of Justice, such an agreement will not be enforceable ${ }^{65}$.

With regard to the responsibility of the mediator, no. 2 of Article 8 of the Mediation Law expressly enshrines the civil liability of the mediator arising from the violation of the duties to which he is subject, both in private and in public mediation systems. At this point, it is necessary to distinguish the mediator's responsibility in the public mediation system, subject to the extracontractual civil liability regime typical of the public law of private mediation systems, where it will be necessary to previously qualify the legal transaction that links the mediator and the mediated parts. Without wishing to delve deeper into this problem, the solution has been based on the concurrence theory, which allows the injured party to support his request in any of the civil liability and consumption theory, in which case contractual civil liability cancels out the extracontractual one ${ }^{66}$. Unlawful acts performed by the mediator in the performance of his or her duties may also constitute an unlawful breach of secrecy under article 195 of the Criminal Code and may also lead to the exclusion of the mediator from the list of mediators of the Directorate General for Justice Policy (DGPJ) for a maximum period of two years ${ }^{67}$.

\section{f) Principle of enforceability}

This principle provided for in Article 9 of the Mediation Law usually gives the mediating agreement an enforceable power, without need for judicial approval. This quality of mediation agreements is an essential feature for their promotion as a means of settling disputes insofar as it provides the mediated parties with a system that ends the conflict by concluding an agreement that has binding effect on the parties and whose compliance may be required by the enforcing party through the executive route. The principle of enforceability enhances the effectiveness of the mediation process by establishing itself as a means of settling disputes that is at the same level in terms of effects between the parties and towards third parties rather than a court decision. By establishing automatic enforceability

65 Thus, in practice, in order to be a mediator in a mediation process in which the broader effects of mediation are intended to be safeguarded, it will be necessary to attend and complete a course, and subsequently be included in the list of mediators of the Ministry of Justice. In Spain, in addition to this initial training, the legislator also imposed compulsory continuing training See Ignacio Gallego Domínguez, La formación del mediador en las normas españolas de mediación", Rafael Cabrera Mercado (Dir.) Pedro M. Quesada López (Coor.), La mediación como método para la resolución de conflictos, Dikinson, Madrid, 2017 pp. 132 and following,

66 Dulce Lopes, Afonso Patrão, Lei da Mediação Comentada... p. 65 and following. The difference in regime is of great relevance inasmuch as the contractual liability is subject to the general limitation period of 20 years as opposed to the extracontractual civil liability, which prescribes within three years, as prescribed in Article 498 of the Civil Code. Another significant difference consists in the presumption of guilt of the debtor, enshrined in no. 1 of Article 799 in the scope of contractual civil liability.

67 See Article 7 of Ministerial Edict no. 344/2013, of 27 November and Article 44 of the Mediation Law. 
of written agreements resulting from mediation, the Portuguese legislation went beyond what was required by the European Mediation Directive, which only states that such agreements could be enforced through a sentence, court decision or other authority act ${ }^{68}$.

In any case, for the executive effectiveness of the agreement obtained through mediation to be automatic, it is necessary to fulfil five requirements, which, as Dulce Pontes and Afonso Patrão refer, are resumed to two: the legality of the agreement and the inclusion of the mediator in a specific list ${ }^{69}$. First of all, the legality of the agreement will be assessed in the light of the possibility of mediating the dispute, i.e. that the dispute is about property or available interests ${ }^{70}$ and that no judicial requirement of the agreement obtained is required by special rule ${ }^{71}$.This legality will also depend on the parties' ability to conclude the agreement in question, to comply with the legal requirements for its implementation, and on the existence of a written and signed agreement whose content does not violate public order ${ }^{72}$. Secondly, it is required that the agreement resulting from the mediation is conducted by a mediator included on the list of conflict mediators organized by the Ministry of Justice ${ }^{73}$. This means that all mediations that meet the legality criteria stated above regardless of whether the mediator is on the Ministry's list or not will be valid. However, the effectiveness of such an agreement will be limited, in particular, in case of default by one of the parties, when the mediator is not on the list of the Ministry of Justice ${ }^{74}$. Notwithstanding the foregoing, the mediated parties may always request the court to ratify the agreement resulting from the mediation. To that end, the parties must make a joint application to any court having jurisdiction in the matter ${ }^{75}$. The intervention of the court aims to ascertain whether the agreement in question relates to a litigation that may be the subject of mediation, the parties' capacity to conclude it, and compliance with the general principles of

68 Article 6 of Directive 2008/52/EC of 21 May 2008 on certain aspects of civil and commercial mediation.

69 Dulce Lopes, Afonso Patrão, Lei da Mediação Comentada... pp. 65-66.

70 See paragraph a) of no. 1 of Article 9 and Article 11 of the Mediation Law. In particular, no. 2 of Article 11 requires that a transaction be entered into on the relevant interests. In turn, the Civil Code defines the transaction as the contract through which the parties prevent or end a dispute as long as they can dispose of those rights and deal with licit deals (see Articles 1248 and 1249 of the Civil Code). Still with regard to cases subject to mediation, see Jorge Morais de Carvalho, "A Consagração legal da mediação ... p. 284 and following.

71 This obligation is foreseen for mediations carried out in the Justice of the Peace Courts, as prescribed in article 56 of Law no. 78/2001, of 13 July in its last edition and for civil suits pursuant to no. 3 of Article 24 of Law 141/2015, of 8 September.

72 See Article 20 of the Mediation Law.

73 See paragraph e) of no. 1 of Article 9 of the Mediation Law.

74 As seen above, this requirement would be related to the principle of jurisdiction provided for in Article 8 of the Mediation Law.

75 See Article 14 of the Mediation Law. 
$\operatorname{law}^{76}$, whose relevance materializes in the formation of a much more solid executive title that does not allow an opposition as comprehensive as other executive titles ${ }^{77}$.

Lastly, mediation agreements concluded in another Member State will benefit from the application of the same regime as Article 14 of the Mediation Law, provided that they comply with the principles and rules of the legal system of that Member State, as provided for in Article 15 of the same legal document.

\section{Cases eligible for mediation}

As can be inferred from the above, not all matters liable to create conflict are susceptible to mediation. However, although it is true that initially a stricter position of cases eligible for mediation was postulated, currently there is a fairly widespread acceptance of mediation in areas traditionally closed to such as criminal, labour, fiscal and administrative matters ${ }^{78}$. Currently, the possibility of mediating a conflict will depend on the type of mediation in question because, as seen above, in the case of criminal mediation ${ }^{79}$, labour mediation ${ }^{80}$,

76 No. 3 of Article 14 expressly indicates the need to verify compliance with the principle of good faith, if the agreement constituted a possible abuse of rights and its content does not infringe the public order. It seems to us, in this case, that there is no justification for imposing different conditions for the same reality.

In fact, whenever possible, the agreement reached in the context of a mediation directed by a registered mediator will be feasible and the mediator must verify only the requirements set forth in point c) of Article 26 of the Mediation Law, i.e., in addition to the aforementioned eligibility for mediation, legitimacy of the parties to intervene in the agreement and the balance of forces of the mediated parties. On the other hand, if it is the court that has such executive power to enforce this executive force, it must go beyond this and attempt to assess such subjective and dynamic realities as those relating to abuse of the right to respect the principle of good faith. On these concepts, see António Menezes Cordeiro, "Do abuso de direito estado das questões e prespectivas", in Ars iudicandi - Estudos em Homenagem ao Prof. Doutor António Castanheira Neves, Vol. II, Coimbra Editora, Coimbra, 2008, pp. 125-176, who states "The abuse of the law and the good faith underlying it represent, (...) a valve of the system: they allow to correct solutions that would otherwise be contrary to elementary vectors"; Mariana França Gouveia, Curso de Resolução ..., p. 81 and following, argues that it will be very difficult for the judge to determine whether or not a mediation agreement violates a mandatory rule on the ground that no evidence is produced in the mediation procedure; Dulce Lopes, Afonso Patrão, Lei da Mediação Comentada... p.72; on the contrary, Jorge Morais de Carvalho, "A Consagração legal da mediação ... p. 289 takes the view that "the control by the judge cannot be limited to compliance with public order".

77 Indeed, opposition based on a judgment as an enforcement order can only be carried out under the terms of article 729 of the Civil Procedure Code.

78 See above mediation systems and Decree-Law no. 10/2011, of 20 January, in the use of the legislative authorization granted by article 124 of Law no. 3-B/2010, of 28 April, in the version introduced by articles 228 and 229 of Law 66-B/2012, of 31 December, which established the Legal Regime of Tax Arbitration.

79 Article 2 of Law 21/2007 of 12 June, which establishes that private and semi-public crimes can be mediated, then imposing some exceptions.

80 See no. 1 of Clause 1 of the Protocol ... which makes the eligibility of the conflict for mediation dependent on the availability of the interest in question, expressly excluding situations resulting from an accident at work. The SML website contains a few examples of some situations that would be included in labour mediation, such as the payment of credits due to the termination of work, change of work place, disciplinary procedures (2017.11.23) http://www.dgpj.mj.pt/sections/gral/mediacao-publica/mediacao-anexos/perguntas-requentes7583/ 
family mediation ${ }^{81}$ and administrative and tax mediation ${ }^{82}$, the widely matters that can be mediated are amply regulated. As far as civil and commercial mediation is concerned, as it is more comprehensive, the criterion delimiting its material scope will result from the conjugation of the principle of ownership and the availability of the rights in question ${ }^{83}$.

Ownership refers to the susceptibility of the pecuniary evaluation of the interest that is the object of conflict between the mediated parties. Thus, whenever we are faced with an interest that can be translated into an economic value, we would be dealing with a matter that can be mediated. In cases where it is not possible to apply the ownership criterion, there is still the possibility, as in voluntary arbitration and in the civil procedure itself, of applying the criterion of the availability of the law that is extended to the possibility of being object of a transaction under the terms of the Article 1249 of the Civil Code ${ }^{84}$.

\section{The mediation procedure}

Knowing that the mediation procedure, albeit structured, is characterized by its great flexibility, closeness and informality, it is important to identify the main stages in which the process is divided ${ }^{85}$. Thus, we can identify the following stages in a mediation procedure:

Hearing of the parties - in the context of pre-mediation, the mediator informs the participants about the procedure, clarifying theirs doubts and then encouraging the signing of the mediation protocol with the legally required requirements ${ }^{86}$. Once the mediation itself has started, the mediator will try, by actively listening to the statements of the parties, to understand what the interests underlying the dispute in question are.

Joint discussion - at this point the parties will present the arguments that support and refute their positions and the mediator must make the parties understand the interests involved in order to open the necessary communication and understanding channels.

81 See Article 4 of Dispatch no. 18778/2007, listing, among other matters, the regulation of parental responsibilities, the use of surname, family house, divorce and separation of assets, allocation and alteration of alimony etc.

82 See Decree-Law no. 10/2011, of 20 January, Edict no. 112-A2011, of 22 March and Article 4 of the New Administrative Arbitration Regulation, available at (2017.11.23) (2017.11.23) https://www.caad.org.pt/files/documentos/CAAD_AANovo_Regulamento_Arbitragem_Administrativa-2015-09-01.pdf

83 Article 11 of the Mediation Law

84 This provision prescribes that the parties cannot compromise on rights that they are not allowed to dispose of, nor on matters relating to illegal business.

85 On the various stages of the mediation process, see Dulce Lopes, Afonso Patrão, Lei da Mediação Comentada... pp. 148 and following; Mariana França Gouveia, Curso de Resolução ..., p. 62 and following, and Enrique César Pérez -Luño Robledo, "La mediación como Proceso? ...", pp. 47 and following, among others. Point a) of no. 1 of Article 591 of the Civil Procedure Code (CPC).

86 See Article 16 of the Mediation Law, including, among other things, the consent of the parties, acceptance of confidentiality, written form, rules of procedure, etc. 
At this stage, it is a matter of making the parties accept that eventually they will not be right about everything.

Establishing the matters in dispute - at this point, the mediator must separate the relevant issues in dispute by proposing to the mediated parties the matters that must be resolved to fully satisfy their interests. The parties should accept or amend the list of proposed matters in order to feel fully committed to finding active solutions to resolve the dispute. It is intended that both parties will be involved in resolving the problem they share.

Looking for ideas - at this stage the parties must actively participate in proposing possible solutions to solve the relevant issues in dispute. It is important that the mediator is creative and encourages the parties to create a wide range of possibilities, suggesting, if he deems it appropriate, the intervention of a technician who can clarify important points for the search for solutions.

Drawing up an agreement - by this point the mediator must be able to draw up an agreement that will enable the interests of the parties to be met and ensure, as far as possible, the maintenance of social peace. The parties can and should intervene at this point in time so that they feel fully identified and bound to the agreement to be made. End of mediation - finally, mediation may hopefully end with an agreement that is satisfactory for the parties. Nonetheless, mediation may be concluded without agreement either on the initiative of the parties or upon the mediator's proposal when there is no adequate balance of forces. It should be pointed out that even when it does not end with an agreement, mediation could be successful if it allows the re-establishment of communication between the parties, thus facilitating possible future solutions.

\section{Conciliation}

The conciliation is specifically regulated in Article 594 of the Civil Procedure Code and assumes that the matter in question is within the powers of the parties in the scope of the process that is directed by the judge. In these circumstances, the judge is bound to promote conciliation at both the prior ${ }^{87}$ and the final hearing ${ }^{88}$, and the parties may seek conciliation at any time in the process ${ }^{89}$. In conciliation, the judge must actively engage in obtaining the fairness solution most appropriate to the terms of the litigation, so we will always be in the domain of a legal evaluation of the dispute, unlike what happens in mediation, where 
the resolution of the dispute is centred in the interests of the parties. In conciliation, the judge would make a preliminary assessment of the grounds of each party, warning about the weaknesses of each of the claims, predicting a possible outcome and proposing, consequently, the terms of an agreement to settle the dispute.

Once conciliation has been attempted and deemed not possible, in whole or in part, the specific solutions suggested by the judge and the grounds which, in the opinion of the parties, justify the continuation of the dispute, should be recorded in the minutes. At this point we also have a major difference between conciliation and the mediation procedure, where the parties, at any time in the process and without the obligation to justify it, may withdraw from it or refuse the agreement reached ${ }^{90}$.

Conciliation is also possible to be conducted at the Justice of the Peace Courts ${ }^{91}$ and also applies to arbitration, sharing the common characteristic with that held in state courts, i.e. it is conducted by a third party who has decision-making power in the matter ${ }^{92}$.This quality of the third party is decisive because, as is clear from the Mediation Directive, attempts made by the court or the judge to settle a dispute in the context of the legal proceedings relating to the dispute in question will not be considered as mediations, nor in cases when the court or the judge of the case requests the aid or the opinion of an expert ${ }^{93}$. However, it may be considered mediation when the mediator is a judge who has no decision power in the case.

A characteristic of conciliation is that the third party who attempts the rapprochement between the disputing parties has an interest, albeit an indirect one, in resolving the dispute in that it will entail closing another case without having to spend time and efforts performing all the legally required procedures.

This third judge, having the power to decide, may influence, albeit involuntarily, the freedom of the parties in that they are given a forecast of the possible outcome of the process $^{94}$. Moreover, although it is not impossible, it will be difficult for the judge to propose an

90 See no. 4 of Article 594 of CPC as opposed to paragraphs 2 and 3 of Article 4 of the Mediation Law.

91 See no. 1 of Article 26 of Law 78/2001.

92 With regard to arbitration, no. 4 of Article 39 and Article 41 of Law 63/2011, of 14 December, provide for the execution of a transaction between the parties that has been understood in the sense that the arbitrator can carry out the conciliation, but in this case it must count on the consent of the parties.

93 Statement 12 and Article 3 of Directive 2008/52/EC of 21 May 2008. As Mariana França Gouveia, Curso de Resolução ..., p. 88 states, one of the justifications of this exclusion is the impossibility of applying the principle of confidentiality to this type of mediations.

94 In Spanish doctrine, other differences are pointed out, as stated by José Martín Ostos, Introducción al Derecho Procesal, Astigi, Seville 7th Ed., 2016, pp. 104 and following. "unlike the classic conciliation in which the conciliator adopts a passive attitude, in mediation the solution of a conflict between parties is entrusted to latter and to the mediator"; or Javier Alés Sioli, Juan Diego Mata Chacón, Manual Práctico para Mediadores. El misterio de la mediación. Como gestionar un conflicto desde sus cenizas., Atelier, Barcelona, 2016, p. 107, "the conciliator does not intervene in the solution, but rather tells them to do so and if not, he draws up a document declaring the non-existence of compromise. While the 
agreement to the parties for a fairer settlement of the dispute, when the parties themselves defend their positions without addressing the interests that are at their basis and without having produced proof.

It follows from the above that the distinction between conciliation and mediation is based not only on the different capacity of the third party involved in the resolution of the conflict but also on the different objectives pursued by the procedure itself, on the different levels of stakeholder participation and finally, the lack of concern about the future relationship between the parties to the conflict.

\section{Final considerations}

The promotion of mediation in Portugal underwent a major advance due to the effort of the legislator to positivize the principles and basic rules that should characterize this type of procedure, attributing the desirable degree of legal certainty and safety to its development. However, it is true that the spread of mediation as a suitable means of settling disputes is the result of a greater effort by the State, mediation centres, universities, lawyers, and other agents near the public in order to unveil the natural, but unjustified fears about mediation.

Mediation is not a substitute for ordinary jurisdiction, but it is also not subservient to it, and a definitive decision with executive power can be obtained by resorting to it, enabling solving the problem of the parties in a inexpensive, participatory, swift and effective way. The main inconvenience that can be attributed to mediation is related to the possible bureaucracy, because if it is frustrated, it will always be needed to resort to court. However, this constraint seems to be insignificant in relation to the potential benefits of mediation, especially in view of the suspension of the limitation and expiry periods that occurs with the start of mediation.

In mediation, the mediator is the main protagonist, but his role must be invisible, which allows the parties to dominate the course of the procedure by actively collaborating in solving their problems and deciding jointly to choose the best possible solution in order to satisfy their interests. This prevents the frustration of being on the verge of obtaining a decision from a third party who may not have realized what conflicting interests lie behind the dispute. 
The professional practice of mediation requires the observance of several principles and the fulfilment of multiple duties, such as impartiality, independence, competence and responsibility that broadly guarantee the legal certainty of the procedure, granting the agreement obtained executive nature, without prejudice to its legal homologation.

Currently, citizens can use mediation to solve a wide range of issues related to their daily lives. As we have seen, the possibility of using mediation is associated with ownership and availability of the rights concerned, without prejudice to the specific regimes in others areas such as labour, criminal law, family law, administrative law, tax law, etc. Thus, in our opinion, resorting to the judiciary, which is more time-consuming, formal and demanding, should only be considered as a complement, thus efficiently managing public and private resources, without neglecting the protection of the interests involved.

Finally, it seems to us that the publication and dissemination of adequate statistical information by mediation centres is an essential tool to demonstrate the beneficial effects attributed to mediation ${ }^{95}$. As a result, it is desirable to provide information on the average duration of mediation procedures in time and number of meetings, the relationship between the sacrifice and benefit of the parties compared with the positions initially adopted, the level of satisfaction of the parties, the cost of mediation and monitoring, after one or two years of compliance with any agreement reached. All these items imply the demanding task of collecting and processing information but they form the foundations that will allow a solid and stable construction of the mediation edifice, showing its advantages for the general population and for legal professionals, whether lawyers, jurists, judges, etc.

95 Jordi Nieva-Fenoll, “Mediación y Arbitraje: Una ilusión decepcionante?”, Rafael Cabrera Mercado (Dir.) Pedro M. Quesada López (Coor.), La mediación como método para la resolución de conflictos, Dikinson, Madrid, 2017, pp. 23 and following state that "reliable statistics about the success of mediation are difficult to obtain because they are partial, insufficient in terms of data or apparently biased". 